\title{
A case of multisystem sarcoidosis on 18F-FDG PET/CT
}

\section{F18-FDG PET/BT'de multisistem sarkoidozlu bir olgu}

\author{
๑Seval Erhamamc1 ${ }^{1}$, @Saime Ramadan², ĐBülent Yaşar ${ }^{3}$ \\ ${ }^{1}$ Department of Nuclear Medicine, Baskent University Faculty of Medicine, Baskent University Istanbul Hospital, Istanbul, Turkey \\ ${ }^{2}$ Department of Pathology, Baskent University Faculty of Medicine, Baskent University Istanbul Hospital, Istanbul, Turkey \\ ${ }^{3}$ Department of Gastroenterology, Istanbul Medipol University, Çamlıca S.U.A.M. Hospital, Istanbul, Turkey
}

Cite this article as/Bu makaleye atıf için: Erhamamci S, Ramadan S, Yasar B. A case of multisystem sarcoidosis on 18F-FDG PET/CT. J Health Sci Med 2020; 3(4): 487-489.

\begin{abstract}
We described a 67-year-old woman with uncommon distribution of multisystem sarcoidosis to disseminated lymph node, lung, liver and sinonasal region on 18F-FDG PET/CT imaging, which showed confounding scintigraphic features of mimicking widespread malignancy due to high metabolic uptake. The present case emphasizes the importance of whole-body assessment by PET/CT in multisystem sarcoidosis associated with rare sinonasal involvement and also the selection of the biopsy site by PET-guidance.
\end{abstract}

Keywords: Sinonasal sarcoidosis, extrapulmonary sarcoidosis, 18F-FDG PET/CT

\section{ÖZ}

18F-FDG PET/BT görüntülemede multisistem sarkoidozun yaygın olmayan lenf nodu, akciğer, karaciğer ve sinonazal bölgeye dağılımı olan ve yüksek metabolik tutulum nedeniyle yaygın maligniteyi taklit eden karıştırıcı sintigrafik özellikler gösteren 67 yaşında bir kadın tanımladık. Bu vaka, nadir sinonazal tutulumla ilişkili multisistem sarkoidozda PET/BT ile tüm vücut değerlendirmesinin ve PET kılavuzluğunda biyopsi yerinin seçilmesinin önemini vurgulamaktadır.

Anahtar Kelimeler: Sinonazal sarkoidoz, ekstrapulmoner sarkoidoz, F18-FDG PET/BT

\section{INTRODUCTION}

Sarcoidosis, a chronic inflammatory disease of unknown etiology, characterized by noncaseating granulomas, most commonly affects pulmonary and mediastinal involvement (1-5). Extrapulmonary sarcoidosis is seen in $25-50 \%$ of cases, usually associated with thoracic involvement (1). Extrapulmonary sarcoidosis can be involved multiple organ systems, such as the peripheral lymph nodes, liver, spleen, bones, heart, kidneys, skin, eyes, muscles and central nervous system (2-7).

18F-FDG PET is a non-invasive diagnostic imaging technique widely used in oncological clinical practice, and also provides a valuable assessment of infectious and inflammatory diseases (1-5). Sarcoidosis may exhibit characteristic thoracic PET findings related to its predominant pulmonary and mediastinal involvement (1-5). Disseminated lymph node and extrathoracic lesions may mimic widespread high metabolic metastases or diffuse lymphomatous disease on 18F-FDG PET imaging (4-7). This case report illustrates an example of uncommon distribution of multisystem sarcoidosis to disseminated lymph node, lung, liver and sinonasal region on 18F-FDG PET/CT imaging, which showed confounding scintigraphic features of mimicking widespread malignancy due to high metabolic uptake. 


\section{CASE REPORT}

A 67-year-old woman without a significant medical history, non-smoker admitted with fatigue and dyspnea. Physical examination and initial laboratory results were unremarkable. Abdominal CT revealed hypodense lesion in the left lobe of liver and wall thickening in the caecum localization. However, no malignancies were determined by colonoscopy. Chest CT showed bilateral multiple pulmonary nodules, and enlarged mediastinal and hilar adenopathy, prompting referral for $\mathrm{PET} / \mathrm{CT}$ to assess for malignancy of unknown origin. PET imaging revealed widespread foci of intense 18F-FDG uptake in multiple lymph nodes, lung, liver, and sinonasal region (Figure 1). No primary malignancy was identified, findings were interpreted as highly concerning for granulomatous disease, and recommended transbronchial or inguinal lymph node biopsy for differential diagnosis from malignancy. Histopathological examination of excisional biopsies from the right inguinal lymph node led to a diagnosis of nonnecrotizing granuloma with asteroid body which is highly suggestive of sarcoidosis (Figure 2). The patient was started on a regimen of systemic steroids.

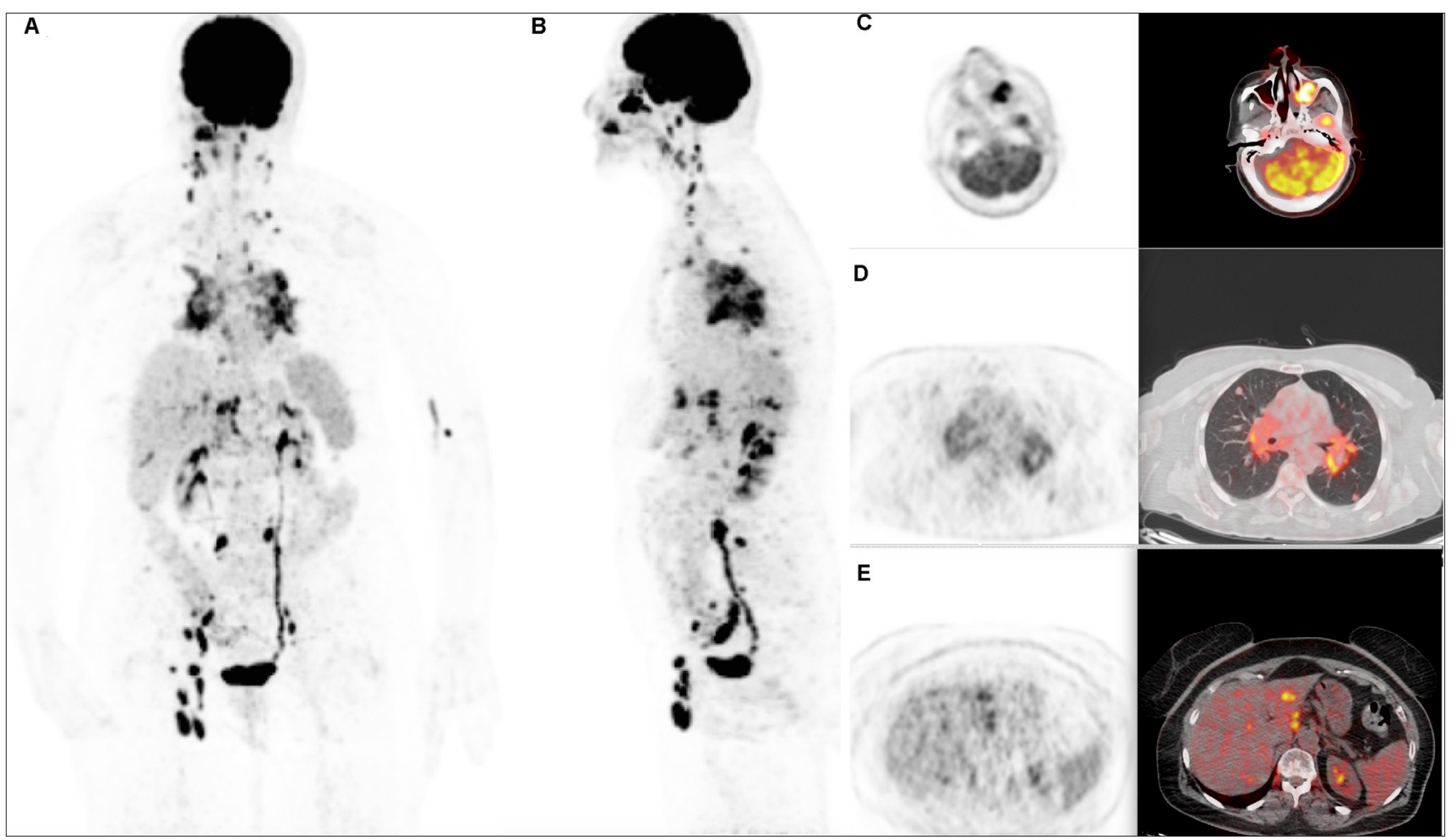

Figure 1. Maximum intensity projection anterior (A) and lateral (B), transaxial PET and fusion PET/CT (C-E) images revealed widespread foci of high 18F-FDG uptake in multiple lymph nodes including bilateral cervical, supraclavicular, mediastinal, hilar, abdominal and right inguinal nodes (largest was $2.0 \mathrm{~cm}$ in diameter with SUVmax =18.5), in left maxillary sinus and left nasal concha (SUVmax=31.4); in numerous peribronchovascular region (SUVmax $=11.8$ ) and parenchymal nodules in both lungs, in the liver $(\mathrm{SUVmax}=11.7)$. No primary malignancy was identified.

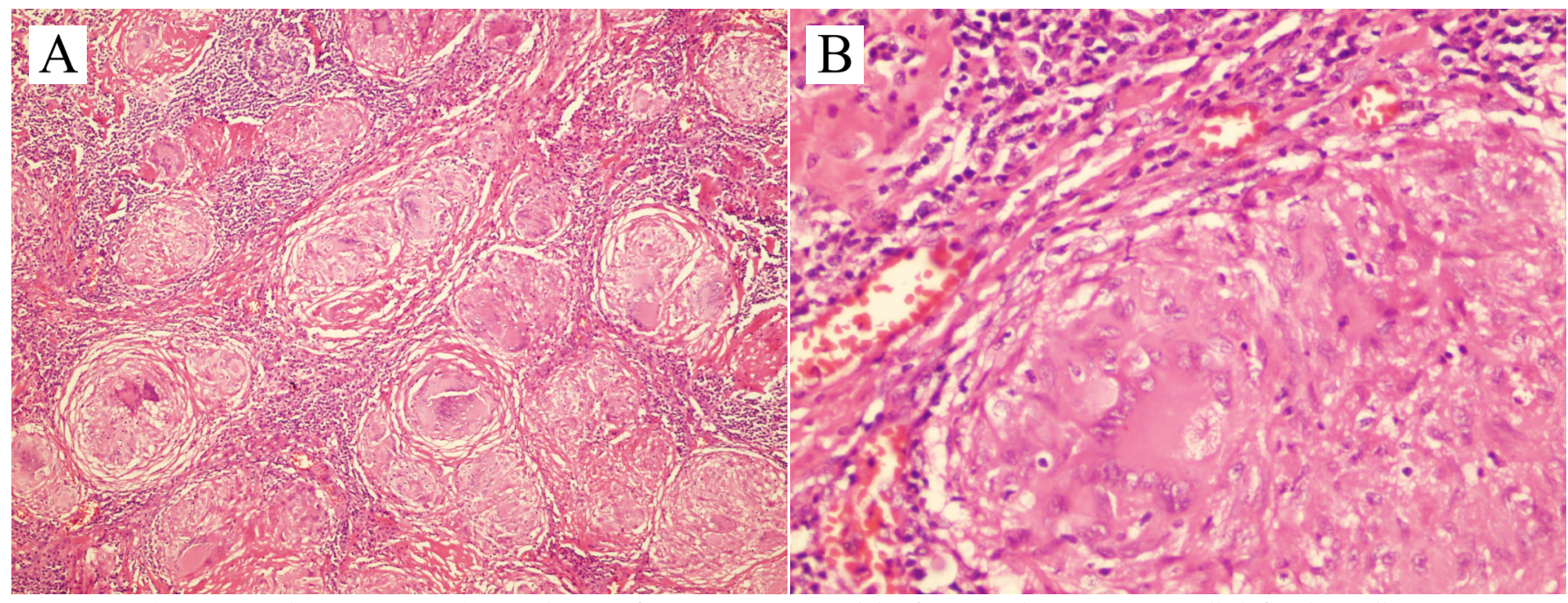

Figure 2. (A) Hematoxylin-eosin stain (original magnification $\times 100$ ): Nodal effacement by numerous well-defined, small nonnecrotizing granulomas composed of epithelioid cells with Langhans giant cells and lymphocytes. (B) Hematoxylin-eosin (original magnification $\times 400$ ): Star-like asteroid body within giant cell not specific but compatible with sarcoidosis. 


\section{DISCUSSION}

18F-FDG PET/CT can significantly contribute to the management of multisystem sarcoidosis because it can detect active inflammatory granulomatous disease (13). 18F-FDG PET/CT can increase the accuracy of the diagnosis of extrathoracic involvement due to wholebody functional mapping of active inflammatory sites (4). However, active sarcoidosis lesions are known to be hypermetabolic like malignancies on 18F-FDG PET/ $\mathrm{CT}$, and may cause to misinterpretation on imaging (5-7). Malignancies can not be ruled out based on hypermetabolic lesions; therefore, a biopsy was required to confirm the diagnosis. 18F-FDG PET/CT may guide the selection of the biopsy site.

Extrathoracic sarcoidosis is most often associated with thoracic involvement (1-3). Detecting extrathoracic lesions is sometimes difficult by physical examination, standard thoracic radiography or CT. 18F-FDG PET/ CT may be helpful in patients with sarcoidosis for determining the intrathoracic and extrathoracic extensity of disease, detecting active disease and accessing the response to treatment (2-4). In the current case, thoracic involvement and also extrathoracic disseminated lymph node, liver and sinonasal involvement was successfully revealed by $18 \mathrm{~F}-\mathrm{FDG}$ PET/CT imaging. The most common extrathoracic involvement was reported the abdomen, which includes liver, spleen, biliary tree, peritoneum, and lymphatic sarcoidosis (2-7). Hepatic involvement is encountered in $50-80 \%$ of cases in autopsy specimens (3). Hepatic involvement usually asymptomatic until advanced stage of the disease, is characterized by enlargement, mottled pattern of FDG accumulation, or scattered small nodular granulomatous lesions on cross-sectional imaging (1-8). This may be associated with an enlargement of abdominal lymph nodes close to the liver hilus or in celiac regions, as in our case.

Sinonasal involvement in sarcoidosis is uncommon, account for less than $5 \%$ of cases, and is usually seen with advanced stage of the disease (9). Involvement of sinonasal mucosa could be isolated, or a part of multisystem involvement. Sinonasal involvement is most likely underdiagnosed type of sarcoidosis because it is usuallly occult lesion. Even if a biopsy is required to confirm sarcoidosis, PET/CT imaging may play an important role in diagnosis and treatment follow-up (9). Unfortunately, biopsy can not be performed on newly detected sinonasal areas due to technical and ethical reasons. The changes in FDG uptake intensity on 18F-FDG PET/CT may reflect the effectiveness of medical treatment and provide a change in therapeutic strategy.
The present case emphasizes the importance of wholebody assessment by 18F-FDG PET/CT in multisystem sarcoidosis associated with rare sinonasal involvement and also the selection of the biopsy site by PET-guidance. In addition, PET/CT provides prognostic information and guides the therapeutic management.

\section{ETHICAL CONSIDERATIONS}

Informed Consent: Written informed consent was obtained from all participants who participated in this study.

Referee Evaluation Process: Externally peer-reviewed.

Conflict of Interest Statement: The authors have no conflicts of interest to declare.

Financial Disclosure: The authors declared that this study has received no financial support.

Author Contributions: All of the authors declare that they have all participated in the design, execution, and analysis of the paper, and that they have approved the final version.

\section{REFERENCES}

1. Soussan M, Augier A, Brillet PY, Weinmann P, Valeyre D. Functional imaging in extrapulmonary sarcoidosis: FDG-PET/ CT and MR features. Clin Nucl Med 2014; 39: 146-59.

2. Braun JJ, Kessler R, Constantinesco A, Imperiale A. 18F-FDG PET/CT in sarcoidosis management: review and report of 20 cases. Eur J Nucl Med Mol Imaging 2008; 35: 1537-43.

3. Rubini G, Cappabianca S, Altini C, Notaristefano A, Fanelli M, Stabile Ianora AA, Niccoli Asabella A, Rotondo A. Current clinical use of 18FDG-PET/CT in patients with thoracic and systemic sarcoidosis Radiol Med 2014; 119: 64-74.

4. Makis W, Palayew M, Rush C, Probst S. Disseminated Multisystem Sarcoidosis Mimicking Metastases on 18F-FDG PET/CT Mol Imaging Radionucl Ther 2018; 27: 91-5.

5. Nguyen BD. F-18 FDG PET imaging of disseminated sarcoidosis. Clin Nucl Med 2007; 32: 53-4.

6. Palmucci S, Torrisi SE, Caltabiano DC, et al. Clinical and radiological features of extra-pulmonary sarcoidosis: a pictorial essay. Insights Imaging 2016; 7: 571-87.

7. Mapelli P, Mangili G, Picchio M, et al. Sarcoidosis mimicking metastatic gynaecological malignancies: a diagnostic and therapeutic challenge?. Rev Esp Med Nucl Imagen Mol 2013; 32: 314-7.

8. Yonenaga Y, Kushıhata F, Inoue H, et al. Sarcoidosis manifesting as hepatic and splenic nodules mimicking ovarian cancer metastases: A case report. Oncol Lett 2015; 10: 2166-70.

9. Braun JJ, Imperiale A, Riehm S, Veillon F. Imaging in sinonasal sarcoidosis: CT, MRI, 67Gallium scintigraphy and 18F-FDG PET/ CT features. J Neuroradiol 2010; 37: 172-81. 